\title{
ALAT BUKTI KETERANGAN AHLI HUKUM PIDANA DALAM PROSES PEMERIKSAAN PERKARA PIDANA
}

\author{
BENGET HASUDUNGAN SIMATUPANG \\ Dosen Fakultas Hukum Univeristas Bengkulu \\ bengetsimatupang@unib.ac.id
}

\begin{abstract}
In the process of examining criminal cases such as corruption cases, the existence of a criminal law expert's statement makes pro and contra, so that is very necessary to do a comprehensive research in the existence of expert criminal law statements. For this reason, the authors are interested in discussing the existence of statement of criminal law experts as one of the evidence in a criminal case. The problem in this research is what are the qualifications of a person to be able to ask for expert criminal law statement to be used as evidence in the trial of a criminal case. This research is a normative juridical legal research with norms approach method and case approach. The results of this research are the qualifications of someone who can provide expert criminal law statement as evidence in the trial of a criminal case is someone who has special expertise regarding knowledge and experience in the field of criminal law. The Criminal Procedure Code (KUHAP) does not provide a limitation on experts and only mentions a person who has special expertise, so that a criminal law expert can be categorized as an expert and the information given can be one of the evidence in court.
\end{abstract}

Keywords: Evidence, Criminal Law Expert Statement, Criminal Case

\begin{abstract}
Abstrak: Dalam proses pemeriksaaan perkara pidana seperti perkara tindak pidana korupsi, keberadaan keterangan ahli hukum pidana menimbulkan pro dan kontra atas kehadirannya dalam memberikan keterangan di persidangan, sehingga sangat perlu dilakukan suatu penelitian secara komprehensif terhadap keberadaan keterangan ahli hukum pidana. Untuk itu penulis tertarik membahas mengenai keberadaan keterangan ahli hukum pidana sebagai salah satu alat bukti dalam pemeriksaan persidangan perkara pidana. Permasalahan dalam penelitian ini adalah apa saja kualifikasi seseorang untuk dapat dimintakan keterangan ahli untuk dapat dijadikan sebagai alat bukti keterangan ahli hukum pidana dalam persidangan perkara pidana. Penelitian ini merupakan penelitian hukum yuridis normatif dengan metode pendekatan norma dan pendekatan kasus. Hasil dari penelitian ini yaitu kualifikasi seseorang yang dapat memberikan keterangan ahli hukum pidana sebagai alat bukti dalam persidangan perkara pidana adalah seseorang yang memiliki keahlian khusus mengenai pengetahuan dan pengalaman dibidang hukum pidana. KUHAP tidak memberikan suatu batasan mengenai ahli dan hanya menyebutkan seorang yang memiliki keahlian khusus, sehingga ahli hukum pidana dapat dikategorikan sebagai ahli dan keterangan yang diberikan dapat menjadi salah satu alat bukti dalam persidangan.
\end{abstract}

Kata Kunci: Alat Bukti, Keterangan Ahli Hukum Pidana, Perkara Pidana.

\section{A. Pendahuluan}

Undang-Undang Dasar 1945 Negara Kesatuan Republik Indonesia menegaskan bahwa setiap orang memiliki hak-hak konstitusional, seorang tersangka berhak untuk mendapatkan perlakuan sesuai dengan prinsip due process of law sebagai konsekuensi 
dari dinyatakanya Negara Republik Indonesia sebagai Negara Hukum, sebagaimana diatur dalam pasal 1 ayat (3) Undang-Undang Dasar 1945, dan hak atas pengakuan, jaminan, perlindungan, dan kepastian hukum yang adil serta perlakuan hukum yang sama dihadapan hukum sebagaimana diatur dalam pasal 28D ayat (1) Undang-Undang Dasar 1945. Sehingga hukum merupakan pemegang kekuasaan tertinggi yang demikian bukan hanya rakyat yang harus mematuhi hukum, akan tetapi Negara (dalam hal ini pemerintah) juga harus tunduk pada hukum yang berlaku.

Alat bukti yang berlaku universal dalam sistem peradilan pidana adalah saksi (witness), ahli (expert), dokumen, dan real evidence atau physical evidence yang dalam konteks hukum acara pidana indonesia dikenal dengan istilah barang bukti. Pembuktian dalam hukum pidana dimulai sejak tahap penyelidikan dan/atau penyidikan sampai pada tahap pemeriksaan di sidang pengadilan. Oleh karena itu, penyidik maupun penuntut dapat meminta keterangan saksi atau ahli mulai dari tahap penyelidikan dan atau penyidikan sampai tahap persidangan. Begitu pula sebaliknya, tersangka dapat meminta keterangan saksi atau ahli mulai dari tahap penyelidikan dan atau penyidikan sampai tahap persidangan (Eddy O.S Hiariej dalam Putusan Mahkamah Konstitusi Nomor 65/PUU-VII/2010).

Pasal 184 ayat (1) Undang-undang No. 8 Tahun 1981 tentang Hukum Acara Pidana yang disingkat dengan KUHAP telah menentukan secara limitatif alat bukti yang sah menurut undang-undang. Di luar alat bukti itu, tidak dibenarkan dipergunakan untuk membuktikan kesalahan terdakwa (Yahya Harahap, 2000: 285). Pada peristiwa atau perkara tertentu, keahlian khusus yang dimiliki seseorang dapat digunakan untuk membantu membuat terang suatu tindak pidana. Kitab UndangUndang Hukum Acara Pidana (KUHAP) mengatur keahlian khusus yang dituangkan dalam bentuk keterangan ahli yang dapat disampaikan mulai tahap penyidikan hingga persidangan. Pada tahap pemeriksaan perkara di pengadilan, keterangan ahli bahkan memiliki kekuatan sebagai salah satu alat bukti yang tertuang dalam Pasal 184 KUHAP sehingga dapat menjadi dasar pertimbangan hakim dalam memutus suatu perkara pidana.

Keterangan ahli sebagai salah satu alat bukti dalam persidangan tidak serta merta dianggap penting karena tidak mengikat hakim. Karena keterngan ahli nilai kekuatan pembuktiannya bebas atau vrij bewijskracht (Yahya Harahap, 2000: 304). Pada satu sisi, hal itu menimbulkan kesan hakim mengabaikan ahli. Di sisi lain, hakim berhak memiliki pertimbangan yang diyakininya (Pasal 183 KUHAP), termasuk dalam mengukur relevansi keterangan ahli dengan perkara serta menilai kapasitas ahli tersebut. Menurut Yahya Harahap, penempatan keterangan ahli sebagai alat bukti yang sah, dapat dicatat sebagai salah satu kemajuan dalam pembaharuan hukum. Setelah saksi ahli disumpah, maka proses pendengaran sama dengan proses pendengaran saksi korban ataupun saksi de charge maupun saksi a de charge; hanya saja dalam hal ini saksi ahli tidak melihat perbuatan ataupun akibat perbuatan terdakwa secara faktual, akan tetapi saksi ahli melihat dari sudut padang ilmu pengetahuan yang ia miliki (Martiman Prodjohamidjojo, 2002: 33).

Keberadaan ahli menimbulkan perdebatan tentang ilmu pengetahuan apa yang dibutuhkan dalam pemeriksaan perkara pidana (Tingkat Persidangan). Pada umumnya, ahli yang dimintai keterangan adalah ahli dari disiplin ilmu pengetahuan dan teknologi yang tidak dikuasai oleh jaksa, penasihat hukum terdakwa, serta hakim. Seperti, ahli kedokteran forensik atau Ilmu Kedokteran Kehakiman, ahli teknologi informasi, ahli bahasa, ahli geologi dan lain sebagainya (Yahya Harahap, 2000: 299). Namun dalam perkembangannya, ada pula ahli hukum pidana dihadirkan dalam persidangan E-ISSN: 2657-0300 Lembaga Penelitian dan Penerbitan Hasil Penelitian Ensiklopedia 305 P-ISSN: 2657-0319 
(terkhusus dalam persidangan tindak pidana korupsi) dan hal ini lah salah satu faktor kenapa penulis melakukan suatu penelitian mengenai keberadaan ahli hukum pidana.

Beberapa kalangan yang menentang keberadaan ahli hukum pidana dalam persidangan berpandangan bahwa hakim telah berkedudukan sebagai ahli hukum yang generalis dan dianggap menguasai hukum (ius curia novit). Pada pemeriksaan kasus korupsi pengadaan buku keputusan KPU dengan terdakwa Tjetjep Harefa (perkara nomor 02/PID.B/TPK/2006/PNJP) dan kasus korupsi penerbitan izin pemanfaatan kayu (IPK) dalam pembangunan lahan kelapa sawit di Kalimantan Timur dengan terdakwa Uuh Ali Yudin (perkara nomor 02/PID.B/TPK/2007/PN.JKT.PST) di Pengadilan Tindak Pidana Korupsi, penolakan dengan alasan ius curia novit disampaikan oleh ketua majelis hakim sendiri. Keinginan Uuh Ali Yudin menghadirkan ahli hukum pidana Chairul Huda ditolak ketua majelis hakim Kresna Menon. Alasannya, majelis hakim telah memiliki keahlian tentang hukum pidana. Kresna Menon menilai seorang ahli hanya diperlukan dalam hal ada keraguan hakim dalam bidang tertentu, misalnya bidang kedokteran (www.hukumonline.com).

Dalam kasus Muhammad Iqbal, jaksa menolak kehadiran ahli hukum pidana Rudy Satriyo Mukantardjo yang diajukan terdakwa dengan alasan yang sama (adagium ius curia novit). Penasihat hukum terdakwa, Maqdir Ismail menyatakan pihaknya berpegang pada Pasal 65 KUHAP yang menyebutkan seorang tersangka atau terdakwa berhak mengajukan saksi yang bukan hanya meringankan tetapi juga menguntungkan. Menurut Maqdir, penolakan jaksa atas keberadaan ahli itu tidak ada alasannya, sebab ahli dihadirkan agar bisa melihat perkara secara jernih. Majelis hakim yang dipimpin Edward Pattinasarani dapat menerima argumen Maqdir dan memberi kesempatan pada ahli Rudy Satriyo untuk menyampaikan keterangan dalam persidangan (www.kapanlagi.com). Berdasarkan permasalahan yang diuraikan di atas, maka penulis melakukan penelitian mengenai keterangan ahli hukum pidana sebagai salah satu alat bukti dalam persidangan, sehingga dapat memperoleh suatu jawaban yang bersifat ilmiah dan komprehensif.

\section{B. Metodologi Penelitian}

Dalam melakukan suatu penelitian, kita tidak akan terlepas dari penggunaan metode. Karena metode merupakan cara atau jalan bagaimana seseorang harus bertindak, maka yang dimaksud metode penelitian adalah suatu kegiatan ilmu yang didasarkan pada sistematika dan pemikiran tertentu yang bertujuan untuk mempelajari satu atau beberapa gejala tertentu, dengan jalan menganalisanya. Agar penulisan hukum ini memenuhi syarat-syarat ilmiah yaitu sebagai tulisan yang mengandung bobot ilmiah, maka salah satu syarat yang harus dipenuhi adalah metode penelitian sebagai jalan atau cara untuk memahami objek yang menjadi sasaran penelitian, sehingga hasil penelitian dapat dipertanggung jawabkan secara ilmiah. Metode penelitian adalah usaha untuk menemukan, mengembangkan dan menguji kebenaran suatu pengetahuan yang dilakukan secara metodologis dan sistematis. Metodologis berarti menggunakan metode-metode yang bersifat ilmiah, sedangkan sistematis sesuai dengan pedoman atau aturan penelitian yang berlaku untuk sebuah karya tulis. Dalam penulisan ini penulis menerapkan tipe penilitian hukum yuridis normatif. Dalam hal ini penulis meneliti bahan pustaka dan bahan sekunder (Soerjono Soekanto dan Sri Mamudji, 2010). Namun juga melalukan suatu wawancara terhadap informan bila dianggap perlu sebagai data pendukung dalam penelitian ini. Dalam penelitian ini, 
pendekatan masalah yang akan digunakan adalah pendekatan norma atau kaedah dan pendekatan kasus (case approach), yaitu penelitian yang bertujuan untuk mempelajari penerapan norma-norma atau kaidah hukum yang dilakukan dalam praktik hukum. Kasus-kasus tersebut dipelajari untuk memperoleh gambaran terhadap dampak dimensi penormaan dalam suatu aturan hukum dan praktik hukum (Johnny Ibrahim, 2006).

\section{Hasil dan Pembahasan}

Pembuktian merupakan sesuatu yang penting dalam hukum pidana. Eddy O.S. Hiariej mengatakan, dalam konteks hukum pidana, pembuktian merupakan inti persidangan perkara pidana karena yang dicari dalam hukum pidana adalah kebenaran Materiil. Van Bemmelen mengemukakan tujuan hukum acara pidana untuk mencari dan menemukan kebenaran, pemberian putusan oleh hakim dan pelaksanaan putusan. Pembuktian dalam hukum acara pidana sebagai suatu upaya mendapatkan keteranganketerangan melalui alat-alat bukti dan barang bukti guna memperolah suatu keyakinan atas benar tidaknya perbuatan pidana yang didakwakan dan mengetahui ada tidaknya kesalahan terdakwa (Rusli Muhammad, 2007). Andi Hamzah menjelaskan juga bahwa dari fungsi hukum acara pidana tersebut, yang terpenting adalah mencari kebenaran dan setelah menemukan kebenaran yang diperoleh dari alat bukti dan bahan bukti, hakim akan sampai kepada putusan (yang seharusnya adil dan tepat), yang kemudian (putusan tersebut) dilaksanakan oleh jaksa.

Dari uraian di atas, dapat disimpulkan bahwa pembuktian dalam perkara pidana merupakan suatu proses yang sangat penting dalam menentukan bersalah atau tidak bersalahnya terdakwa yang diwujudkan dalam suatu bentuk putusan. Yahya Harahap menjelaskan, apabila hasil pembuktian dengan alat-alat bukti yang ditentukan oleh Undang-undang "tidak cukup" membuktikan kesalahan yang didakwakan kepada terdakwa, maka terdakwa "dibebaskan" dari hukuman. Sebaliknya, kalau kesalahan tedakwa dapat dibuktikan dengan alat-alat bukti menurut Pasal 184 KUHAP, maka terdakwa dinyatakan bersalah dan dijatuhkan hukuman.

Eddy O.S Hiariej membagi kedalam enam hal yang menjadi parameter atau alat ukur dalam pembuktian, antara lain: Bewijstheori adalah teori pembuktian yang dipakai sebagai dasar pembuktian oleh hakim di pengadilan. Ada empat teori pembuktian; Pertama adalah positif wettelijk bewijstheori yang mana hakim terikat secara positif kepada alat bukti menurut undang-undang. Kedua adalah conviction intime yang berarti keyakinan semata. Artinya, dalam menjatuhkan putusan, dasar pembuktiannya senata-mata diserahkan kepada keyakinan hakim. Salah satu negara di dunia yang menggunakan conviction intime adalah Amerika. Ketiga, conviction raisonee. Artinya, dasar pembuktian menurut hakim dalam batas-batas tertentu atas alasan yang logis. Keempat, negatif wettelijk bewijsthorie. Artinya, dasar pembuktian menurut keyakinan hakim yang timbul dari alat-alat bukti dalam undang-undang secara negatif.

Bewijsmiddelen adalah alat-alat bukti yang digunakan untuk membuktikan telah terjadinya suatu peristiwa hukum. Rusli Muhammad menjelaskan, Bewijsmiddelen merupakan alat-alat pembuktian yang dapat dipergunakan hakim untuk memperolah gambaran tentang terjadinya perbuatan pidana yang sudah lampau.

Bewijsvoering, secara harfiah Bewijsvoering diartiakan sebagai penguraian cara bagaimana menyampaikan alat-alat bukti kepada hakim di pengadilan. Bagi negaranegara yang cenderung menggunakan due process model dalam sitem peradilan pidananya, perihal Bewijsvoering cukup mendapat perhatian. Dalam due process model, negara menjunjung tinggi hak asasi manusia (hak-hak tersangka) sehingga acap E-ISSN: 2657-0300 Lembaga Penelitian dan Penerbitan Hasil Penelitian Ensiklopedia $\quad 307$ 
kali seorang tersangka dibebaskan oleh pangadilan dalam pemeriksaan praperadilan lantaran alat bukti diperoleh dengan cara yang tidak sah atau yang disebut dengan istilah unlawful legal evidence (cara memperolah bukti bertentangan dengan hukum). Persoalan bewijsvoering di Indonesia cukup mendapat perhatian publik menyangkut penyadapan dan peniyidikan under cover oleh penyidik yang pada dasarnya dapat dikualifikasikan sebagai unlawful legal evidence, namun diperbolehkan undangundang. Dalam perkenbangan terhadap bijzondere delicten (delik-delik khusus) yang diatur di luar Kitab Undang-undang Hukum Pidana, penyadapan boleh dilakukan dalam rangka mengungkap suatu kejahatan.

Bewijslast atau burden of proof adalah pembagian beban pembuktian yang diwajibkan oleh undang-undang untuk membuktikan suatu peristiwa hukum. Dalam praktik, baik jaksa penuntut umum maupun terdakwa atau penasihat hukumnya saling membuktikan di depan persidangan. Lazimnya jaksa penuntut umum akan membuktikan kesalahan terdakwa, sedangkan sebaliknya terdakwa beserta penasihat hukum akan membuktikan sebaliknya bahwa terdakwa tidak terbukti secara sah dan meyakinkan bersalah melakukan tindak pidana yang didakwakan. Suatu kondisi yang mana jaksa penuntut umum dan terdakwa sama-sama membuktikan di sidang pengadilan dinamakan asa pembalikan beban pembuktian "berimbang" seperti dikenal di Amerika Serikat dan juga di Indonesia.

Bewijskracht dapat diartikan sebagai kekuatan pembuktian masing-masing alat bukti dalam rangkaian penilaian terbuktinya suatu dakwaan. Penilaian tersebut merupakan otoritas hakim. Hakimlah yang menilai dan memutuskan kesesuaian antara alat bukti yang satu dengan alat bukti yang lain. Kekuatan pembuktian juga terletak pada bukti yang diajukan, apakah bukti tersebut relevan atau tidak dengan perkara yang sedang disidangkan. Jika bukti tersebut relevan, kekuatan pembuktian selanjutnya mengarah pada apakah bukti tersebut dapat diterima ataukah tidak.

Bewijs Minimum, Secara sederhana, bewijs minimum adalah bukti minimum yang diperlukan dalam pembuktian untuk mengikat kebebasan hakim. Dalam hukum acara pidanan di Indonesia, untuk menjatuhkan pidana kepada terdakwa, paling tidak harus ada dua alat bukti ditambah dengan keyakinan hakim. Artinya untuk menjatuhkan pidana, bewijs minimum-nya adalah dua alat bukti. Ketentuan perihal minimum bukti ini diatur dalam Pasal 183 KUHAP.

Dilihat dari uraian di atas mengenai parameter atau alat ukur pembuktian yang berkaitan Bewijsmiddelen (alat-alat bukti yang digunakan), dalam konteks hukum acara pidana diatur dalam Pasal 184 KUHAP, yang terdiri dari: a) Keterangan saksi; b) Keterangan ahli; c) Surat; d) Petunjuk; dan e) Keterangan terdakwa.

Jadi alat-alat bukti yang dapat digunakan dalam pembuktian hanya terbatas pada alat bukti tersebut. Alat bukti yang berlaku universal dalam sistem peradilan pidana (adalah saksi (witness), ahli (expert), dokumen, dan real evidence atau physical evidence yang dalam konteks hukum acara pidana di Indonesia dikenal dengan istilah barang bukti (Romli Atmasasmita, 2010). Ahli (expert) dalam Kamus Besar Bahasa Indonesia didefinisikan sebagai seseorang yang mahir atau mempunyai keahlian dalam suatu keilmuan. Dalam Kamus Hukum, ahli sebagai terjemahan kata deskundige yang dalam bahasa Belanda diartikan sebagai orang yang memiliki keahlian, kecakapan atas sesuatu bidang ilmu. Sudarsono (2007) mengartikan ahli merupakan orang yang mahir, paham sekali di suatu ilmu (kepandaian); mahir benar. 
California Evidence Code memberikan definisi tentang ahli sebagai seseorang yang dapat memberi keterangan jika ia mempunyai pengetahuan, keahlian, pengalaman, latihan atau pendidikan khusus yang memadai untuk memenuhi syarat sebagai seorang ahli tentang hal yang berkaitan dengan keterangannya. Meneurut Tristram Hodgkinson dan Mark James, definisi ahli mempunyai dua deskripsi. Pertama, berpengalaman, yaitu seorang yang berpengalaman dan mendapatkan kecakapannya dari pengalaman tersebut. Kedua, terlatih oleh pengalaman atau praktik, cakap, terampil sebagaimana seseorang yang memiliki pengetahuan atau keterampilan tertentu dan menjadikan ia sebagai spesialis. Kata "cakap atau terampil" diartikan sebagai memiliki keterampilan atau pengetahuan yang cukup terlatih dan berpengalaman.

Dalam kontek hukam acara pidana, definisi ahli tidak dijelaskan dalam KUHAP, namun memberikan pengertian tentang Keterangan ahli dalam Pasal 1 butir 28 menyatakan bahwa keterangan ahli adalah "keterangan yang diberikan oleh seseorang yang memiliki keahlian khusus tentang hal yang diperlukan untuk membuat terang suatu perkara pidana guna kepentingan pemeriksaan." Selain itu, Pasal 186 KUHAP menyebutkan keterangan ahli ialah "apa yang seorang ahli nyatakan di sidang pengadilan." Yahya Harahap menjelaskan bahwa dari Pasal 1 angka 28 tersebut, dapat ditarik pengertian mengenai keterangan ahli, yakni: a) Keterangan ahli ialah keterangan yang dberikan seorang ahli yang memiliki "keahlian khusus" tentang masalah yang diperlukan penjelasannya dalam suatu perkara pidana yang sedang diperiksa; dan b) Maksud keterangan khusus dari ahli, agar perkara pidana yang sedang diperiksa "menjadi terang" demi untuk penyelesaian pemeriksaan perkara yang bersangkutan.

Dalam penjelasan Pasal 186 KUHAP, dikatakan bahwa "keterangan ahli ini dapat juga sudah diberikan pada waktu pemeriksaan oleh penyidik atau penuntut umum yang dituangkan dalam suatu bentuk laporan dan dibuat dengan mengingat sumpah di waktu ia menerima jabatan atau pekerjaan. Keterangan tersebut diberikan setelah ia mengucapkan sumpah atau janji di hadapan hakim." M. Karjadi dan R. Soesilo menjelaskan, bahwa dalam Pasal 186 ini dapat diketahui bahwa bukti keterangan ahli itu bukan apa yang oleh ahli terangkan di muka penyidik atau penuntut umum walaupun dengan mengingat sumpah diwaktu menerima jabatan atau pekerjaan, tetapi berupa apa yang orang ahli nyatakan di sidang pengadilan setelah ia mengucapkan sumpah atau janji di hadapan hakim. Keterangan yang ahli nyatakan di hadapan penyidik atau penuntut umum dibuat dalam bentuk laporan, yang tergolong kedalam alat bukti surat.

Dari uaraian kedua Pasal tersebut tidak dijelaskan batasan mengenai ahli apa saja yang dapat memberikan keterangan pada waktu pemeriksaan penyidik atau penutut umum maupun pemeriksaan di persidangan. Dari penjelasan tersebut, ketengan ahli dapat diberikan atau dimintakan hanya kepada seseorang yang memiliki keahlian khusus. Pasal 343 Nederlands Strafvordering (Hukum Acara Negara Belanda) memberikan definisi apa yang dimaksud dengan keterangan ahli sebagai berikut: "Pendapat seorang ahli yang berhubungan dengan ilmu pengetahuan yang telah dipelajarinya".

Dalam pasal 179 ayat (1) KUHAP dapat dikategorikan dua kelompok ahli, yaitu ahli kedokteran dan ahli-ahli lainnya. Sehingga keterangan ahli hukum pidana dapat dikatakan juga termasuk kedalam Keterangan ahli sebagai salah satu alat bukti yang di atur dalam Pasal 184 huruf b. Rusli Muhammad menjelaskan bahwa ada beberapa syarat sahnya suatu keterangan ahli, yaitu: a) Keterangan diberikan atau dimintakan E-ISSN: 2657-0300 Lembaga Penelitian dan Penerbitan Hasil Penelitian Ensiklopedia $\quad 309$ P-ISSN: 2657-0319 
kepada ahli, b) Memiliki keahlian khusus dalam bidang tertentu, c) Menurut pengetahuan dalam bidang keahliannya, dan d) Diberikan dibawah sumpah.

Dalam praktiknya, keberadaan ahli hukum pidana dalam memberikan keterangan ahli di persidangan sebagai salah satu alat bukti yang sah pada perkara tindak pidana korupsi yang diajukan oleh terdakwa atau penasehat hukum terdapat beberapa penolakan oleh jaksa penuntut umum maupun hakim. Penolakkan oleh Hakim dapat dilihat pada perkara Korupsi yang mana terdakwanya Tjetjep Harefa dengan Perkara Nomor 02/PID.B/TPK/2007/PN.JKT.PST) dan terdakwa Uuh Ali Yudin dengan Perkara Nomor 02/PID.B/TPK/2007/PN.JKT.PST). sedangkan penolakan oleh Jaksa Penununtut Umum dapat dilihat pada kasus Muhammad Iqbal dan Abdullah Puteh. Semua penolakan atas keinginan terdakwa atau penasehat hukum dalam menghadirkan ahli hukum pidana dalam memberikan keterangan yang dapat dijadikan sebagai alat bukti keterangan ahli berdasarkan kepada asas Ius Curia Novit.

Demikian juga halnya Jaksa penuntut umum Komisi Pemberantasan Korupsi (KPK) Irene Putrie, menjelaskan bahwa: Tidak ada kategorisasi secara eksplisit dalam KUHAP tentang ahli yang diperlukan untuk memberikan keterangan. Adagium Ius curia Novit: Hakim mengetahui hukum, menjadi dasar pula bagi Penuntut Umum.Karena di KPK, kualifikasi jaksa adalah minimal sudah 7 tahun dalam jabatan jaksa, latar belakang pendidikan formal min Pasca Sarjana malah ada yang Doktor serta terus-menerus bergelut dalam persoalan pidana serta hukum acara, maka kami tidak pernah meminta ahli hukum Pidana dalam persidangan (Irene Putrie, 2012).

Sebagaimana telah diurikan di atas, KUHAP tidak menyebutkan batasan yang rinci tentang siapa yang dimaksud dengan ahli yang keterangannya dapat dijadikan sebagai salah satu alat bukti. Sebaliknya, tidak ada pula ketentuan KUHAP yang melarang para pihak untuk menghadirkan ahli hukum pidana dalam memberikan keterangan di persidangan sebagai salah satu alat bukti. Menurut Martiman Prodjohamidjojo, ada kalanya peraturan perundang-undangan seringkali membutuhkan penjelasan lebih lanjut saat diterapkan pada hal-hal yang konkret. Hal tersebut disebabkan oleh kondisi undang-undang yang tidak lengkap seluruhnya dan hakim juga memiliki peran dalam pembentukan hukum (Rafiqa Qurrata A'yun, 2010). Menurut Busyro Muqoddas, pada faktanya mana ada hakim yang tau semua hukum, kehadiran seorang ahli dalam persidangan bukan hal yang tabu sekalipun ahli tersebut memiliki keahlian yang sama dengan hakim (hukumonline.com).

Yahya Harahap menyatakan, hakim pada dasarnya bukan manusia generalis yang serba tahu. Namun, dalam prakteknya sering (hakim) hanya memadai pengetahuan yang ada pada dirinya sekalipun benar-benar kurang paham. Demikian juga halnya dengan Martiman Prodjohamidjojo menyebutkan bahwa: Sebagai asas dalam peradilan, hakim tidak boleh menolak suatu perkara yang diajukan kepadanya sekalipun hukum atau undang-undang tidak mengaturnya. Ia harus menemukan hukum itu. Hal itu bukan berati hakim dianggap tahu segalanya atau dianggap sebagai menusia serba tahu, karena itu ia membutuhkan dan menggunakan keterangan seorang ahli agar memperoleh pengetahuan yang mendalam tentang suatu hal yang menyangkut perkara yang ditangahinya.

Mengacu pada Pasal 65 KUHAP, menerangkan bahwa hak tersangka atau terdakwa untuk mengusahakan dan mengajukan ahli. M. Karjadi dan R. Soesilo berpendapat bahwa mereka yang memiliki keahlian khusus merupakan ahli dari segala bidang. Tidak terdapat batasan ahli apakah yang dimaksudkan KUHAP. Sehingga 
dapat dikatakan bahwa Ahli hukum pidana juga tergolong kedalam ahli yang dapat memberikan keterangan guna membuat terang tindak pidana dan duduknya suatu permasalah hukum. Selain itu, keterangan ahli hukum pidana sebagai salah satu alat bukti dapat membantu pengadilan dalam menemukan kebenaran materil sebagai tujuan dari hukum acara pidana,

Berkaitan dengan asas Ius curia novit tersebut, dapat dilihat bahwa asas tersebut terkandung dalam Pasal 16 ayat (1) Undang-undang Nomor 4 Tahun 2004 tentang Kekuasaan Kehakiman yang berbunyi: "Pengadilan tidak boleh menolak untuk memeriksa, mengadili, dan memutus suatu perkara yang diajukan dengan dalih bahwa hukum tidak ada atau kurang jelas, melainkan wajib untuk memeriksa dan mengadilinya." Namun, pada penjelasan pasal 16 undang-undang tersebut tidak memberikan penjelesan lebih lanjut mengenai asas ius curia novit.

Latar belakang sejarah ius curia novit yang diadaptasi dalam ketentuan hukum pasal tersebut, dapat dilihat dalam konsiderans Putusan Mahkamah Konstitusi atas Perkara Nomor 061/PUU-II/2004 Tentang Pengujian Pasal 16 Undang-Undang No. 4 Tahun 2004 Tentang Kekuasaan Kehakiman. Dalam pertimbangan hukum yang terdapat pada putusan tersebut, dijelaskan bahwa latar belakang sejarah dari frase Pasal 16 Undang-Undang No. 4 Tahun 2004 didasarkan pada adagium ius curia novit, yang bermakna pengadilan mengetahui hukumnya (de rechtbank kent het recht), artinya memahami penyelesaian hukum atas perkara yang diajukan kepadanya. Adagium tersebut telah dijadikan salah satu asas hukum dan dimuat dalam Code Civil yang merupakan bagian dari Code Napoleon di Perancis dan selanjutnya diserap dan diterima secara universal. Di Belanda, asas tersebut dimuat dalam Algemene Bepalingen van Wetgeving $(\mathrm{AB})$ yang mengatur tentang hukum perdata dan hukum dagang. Selanjutnya, Indonesia (Nederlandsche Indie) mencantumkan asas tersebut dalam Pasal 22 Algemene Bepalingen van Wetgeving voor Nederlandsche Indie (Staatsblad 1847 Nomor 23). Dengan menelusuri sejarah adagium itu, hakim konstitusi berpendapat bahwa ketentuan yang tercantum dalam Pasal 16 Undang-Undang No. 4 Tahun 2004 Tentang Kekuasaan Kehakiman itu bukan hanya merupakan ketentuan umum (algemene norm), melainkan merupakan asas yang dianut secara universal dalam sistem peradilan.

Dari penjelasan di atas, dapat disimpulkan bahwa keradaan asas ius curia novit bukan mengandung makna untuk menolak ahli hukum pidana dalam kehadirannya di persidangan untuk memberikan keterangan, tetapi sebagai suatu larangan terhadap hakim (pengadilan) untuk menolak perkara yang diajukan kepadanya. Sehingga hakim dituntut untuk dapat melakukan suatu penafsiran terhadap aturan perundang-undangan dan melakukan suatu penemuan hukum (recht finding) dalam menangani perkara yang tidak ada hukum positif (tertulis) yang mengaturnya secara tegas. Jadi merupakan suatu kekeliruan apabila Hakim maupun jaksa penuntut umum melandaskan argumennya kepada asas ius curia novit dalam menolak kehadiran ahli hukum pidana dalam memberikan keterangan ahli sebagai alat bukti dalam proses pemeriksaan dipersidangan dan dapat dikatakan merupakan suatu pelanggaran terhadap hak terdakwa berdasarkan Pasal 65 KUHAP. Dilihat penjelasan yang diberikan oleh Arthur Best, bahwa keterangan (kesaksian) ahli juga dapat terkait mengenai topik substansi hukum yang mendasari suatu perkara atau sengketa sehingga dibutuhkan keterangan (kesaksian) ahli. Dalam hal ini, tentu keterangan yang dibutuhkan juga termasuk keterangan yang diberikan oleh ahli hukum pidana jika terkait dengan perkara pidana.

Pasal 180 ayat (1) KUHAP dalam hal diperlukan untuk menjernihkan duduknya persoalan yang timbul di sidang pengadlian, hakim ketua sidang dapat minta E-ISSN: 2657-0300 Lembaga Penelitian dan Penerbitan Hasil Penelitian Ensiklopedia 311 
keterangan ahli dan dapat pula minta agar diajukan bahan baru oleh yang berkepentingan. Eddy O.S Hiariej menyatakan bahwa, dapat saja keterangan ahli juga menyangkut masalah hukum terkait dengan dasar hukum atau alasan yang menjadi pokok perkara termasuk pula di dalamnya adalah analisis atau pengertian elemenelemen suatu tindak pidana yang didakwakan.

Dari semua uraian di atas, dapat diambil suatu konklusi bahwa kerakteristik seseorang yang dapat memberikan keterangan ahli sebagai ahli hukum pidana dalam persidangan tindak pidana korupsi terdiri atas beberapa aspek, yaitu: a) Seseorang yang memiliki keahlian khusus mengenai pengetahuan dibidang hukum pidana. yang biasanya adalah seorang akademisi, seperti seorang dosen pada perguruan tinggi; dan b) Seseorang yang memiliki pengalaman dibidang hukum pidana, seperti seorang praktisi hukum.

Selain karakteristik yang dimiliki oleh ahli hukum pidana diatas, seorang ahli hukum pidana dalam menyampaikan keterangan dalam persidangan harus memenuhi beberapa syarat teknis, yaitu: a) Harus membawa surat biodata mengenai identitas diri; b) Harus membawa surat pengantar atau surat tugas dari institusi dimana ia bernaung, dalam hal seorang dosen (Kalangan akademisi) berarti surat yang dibawa adalah surat yang dikeluarkan oleh Fakultas atas seizin Dekan; dan c) Bersedia diambil sumpahnya sebelum memberikan keterangan dalam persidangan.

\section{Penutup}

Kualifikasi seorang yang dapat dimintakan keterangan ahli untuk dijadikan sebagai alat bukti keterangan ahli hukum pidana dalam persidangan perkara pidana, terdiri atas beberapa aspek, yaitu seseorang yang memiliki keahlian khusus mengenai pengetahuan dibidang hukum pidana yang biasanya adalah seorang akademisi, seperti seorang dosen pada perguruan tinggi dan seseorang yang memiliki pengalaman dibidang hukum pidana, seperti seorang praktisi hukum. keradaan asas ius curia novit bukan mengandung makna untuk menolak ahli hukum pidana dalam kehadirannya di persidangan untuk memberikan keterangan, tetapi sebagai suatu larangan terhadap hakim (pengadilan) untuk menolak perkara yang diajukan kepadanya. Sehingga hakim dituntut untuk dapat melakukan suatu penafsiran terhadap aturan perundang-undangan dan melakukan suatu penemuan hukum (recht finding) dalam menangani perkara yang tidak ada hukum positif yang mengaturnya secara tegas.

\section{Daftar Pustaka}

Andi Hamzah, 2008, Hukum Acara Pidana Indonesia, Edisi Kedua, Sinar Grafika, Jakarta.

, 2008, Pemberantasan Korupsi melalui Hukum Pidana Nasional dan Internasional, Rajawali, Jakarta.

A. Gumilang, 1993, Kriminalistik Pengetahuan tentang Teknik dan Taktik Penyidikan, Angkasa, Bandung.

Bambang Waluyo,2008,Pidana dan Pemidanaan,Sinar Grafika,Jakarta.

Baharuddin Lopa, 2001, Kejahatan Korupsi dan Penegakan Hukum, Kompas, Jakarta.

Bismar Siregar,1983,Hukum Acara Pidana, Cet. 1,Badan Pembinaan Hukum Nasional

Departemen Kehakiman, Jakarta.

Chaerudin, Syaiful Ahmad Dinar, dan Syarif Fadillah, 2008, Strategi Pencegahan dan Penegakan Hukum Tindak Pidana Korupsi, Refika Aditama, Bandung. 
Djoko Prakoso, 1988, Alat Bukti dan Kekuatan Pembuktian di dalam Proses Pidana, Liberty, Yogyakarta.

Djoko Sumaryanto, 2009, Pembalikan Beban Pembuktian, Prestasi Pustakaraya, Jakarta.

Eddy O.S. Hiariej, 2012, Teori \& Hukum Pembuktian, Penerbit Erlangga, Jakarta.

Elwi Danil, 2011, Korupsi: Konsep, Tindak Pidana, dan Pemberantasannya, Rajawali Pers, Jakarta.

Evi Hartanti, 2009, Tindak Pidana Korupsi, Edisi 2, Sinar Grafika, Jakarta.

Hadari Djenawi Tahir, 1981, Pokok-Pokok Dalam Kitab Undang-Undang Hukum Acara Pidana, Alumni, Bandung.

Johnny Ibrahim,2006,Teori dan Metodologi Penelitian Hukum Normatif, Cet II, Bayumedia, Malang.

Leden Marpaung, 2011, Proses Penanganan Perkara Pidana (Penyelidkan \& Penyidikan), Cet- ketiga, Sinar Grafika, Jakarta.

Lilik Mulyadi, 2000, Tindak Pidana Korupsi: Tinjauan khusus terhadap proses Penyidikan, Penuntutan, Peradilan serta Upaya Hukumnya menurut Undangundang Nomor 31 Tahun 1999, Citra Aditya Bakti, Bandung.

Martiman Prodjohamidjojo,2002.Strategi memenangkan perkara,Jakarta,Pradnya paramita.

Rafiqa Qurrata A'yun, 2010, Kualifikasi dan Obyektifitas ahli dalam Pemeriksaan Perkara Pidana, Tesis, Universitas Indonesia.

Romli Atmasasmita, 2010, Sistem Peradilan Pidana Kontemporer, Kencana, Jakarta.

Rusli Muhammad, 2007, Hukum Acara Pidana Kontemporer, Citra Aditya Bakti, Bandung.

Yahya Harahap, 2000, Pembahasan Permasalahan dan Penerapan KUHAP (Edisi Kedua), Sinar Grafika, Jakarta.

P.A.F. Lamintang, 1997, Dasar-dasar Hukum Pidana Indonesia,cet 3, Citra Aditya Bakti, Bandung.

Soesilo, R. 1995 . Kitab Undang-Undang Hukum Pidana (KUHP) serta KomentarKomentarnya Lengkap Pasal Demi Pasal, Politea, Bogor.

S Tanusubroto,1989, Dasar-Dasar Hukum Acara Pidana. Cet. 2, Armico, Bandung.

Soerjono soekamto, 2010,Pengantar Penelitian Hukum, Jakarta, UI-Press.

Soerjono Soekanto dan Sri Mamudji, 2010, Penelitian Hukum Normatif Suatu Tinjauan Singkat, Rajawali Pers, Jakarta.

Sudarsono, 2007, Kamus Hukum, Rineka Cipta, Jakarta.

Wojowasito-W.J.S. Poerwadarminta,Kamus Lengkap Inggris-Indonesia, IndonesiaInggris,Hasta, Bandung.

www.hukumonline.com/detail.asp?id=16916\&cl=Berita.

www.kapanlagi.com/h/jpu-tolak-saksi-ahli-penasihat-hukumuhammad-iqbal.html.

www. cetak.kompas.com/read/xml/2010/05/04/03175689/.

Undang-Undang Dasar Negara Republik Indonesia Tahun 1945

Undang-Undang No. 8 Tahun 1981 Tentang Hukum Acara Pidana

Putusan Mahkamah Konstitusi Nomor 65/PUU-VIII/2010. 